\title{
EFFECT OF SUPPLEMENTARY MILK FEEDING ON GROWTH AND SURVIVAL OF SANTA INÊS LAMBS
}

\author{
Concepta Margaret McManus ${ }^{1}$, Edgard Franco Gomes ${ }^{2}$, Tiago Prado Paim ${ }^{3}$, \\ HELDER LOUVANDINI ${ }^{4}$, BRUNO DALLAGO ${ }^{5}$, BARBARA OLIVEIRA BORGES ${ }^{6}$, AlINE ZORZAN $^{7}$, \\ PAUlO DE MELlO TAVARES LimA ${ }^{8}$

\footnotetext{
${ }^{1}$ Professora Doutora da Universidade de Brasília, Brasília DF, Brasil. concepta@unb.br ${ }^{2}$ Pós-Graduando do Centro de Energia Nuclear da Universidade de São Paulo, Piracicaba, SP, Brasil. ${ }^{3}$ Médico Veterinário, Mestre, do Instituto Federal Goiano, Iporá, GO, Brasil

${ }^{4}$ Professor Doutor do Centro de Energia Nuclear da Universidade de São Paulo, Piracicaba, SP, Brasil.

${ }^{5}$ Médico Veterinário, Doutor, da Universidade de Brasilia, Brasília DF, Brasil.

${ }^{6}$ Médica Veterinária, Mestre pela Universidade Estadual Paulista, Botucatu, SP, Brasil.

${ }^{7}$ Graduanda da Universidade de Brasilia, Brasília DF, Brasil.

${ }^{8}$ Pós Graduando do Centro de Energia Nuclear da Universidade de São Paulo, Piracicaba, SP, Brasil.
}

The objective of this experiment was to evaluate the effect of alternative methods of feeding on the performance and mortality rate of suckling lambs. Eighty-four Santa Inês lambs, twins and singles, half male and half female, were used. The animals were divided into three groups: A (control), B (bovine milk) and C (bovine milk plus Multimixture). The experiment began when lambs were three weeks old and finished at weaning at 2 months of age. Each animal from group B received $200 \mathrm{~mL}$ of bovine milk daily; group $\mathrm{C}$ received $200 \mathrm{~mL}$ of bovine milk plus $20 \mathrm{~g}$ of Multi-mixture daily. Weaning Weight (WW) was $10.90,13.20$ and $13.59 \mathrm{~kg}$, respectively for groups A, B and C. Daily Weight Gain (DWG) was 126, 163 and 168 ${\text { g. } \text { day }^{-1}}^{-1}$ respectively. The mortality rate was higher $(\mathrm{p}<0.05)$ in group A than in group B and C. Gender influenced significantly $(p<0.05)$ the $D W G$ and WW. DWG and WW were lower for the animals that died compared to the animals that survived: $7.94 \mathrm{~kg}$ against $13.51 \mathrm{~kg}$ (WW) and $77 \mathrm{~g}$ against $165 \mathrm{~g}$ (DWG) respectively. The twins had lower $(\mathrm{P}<0.05) \mathrm{WW}$ and DWG when compared to the singles. The use of milkreplacers with or without Multi-mixture is effective and it can increase the productivity of the system.

KEYWORDS: cassava leaf, egg shell, mortality, weight gain.

\section{EFEITO DA SUPLEMENTAÇÃO LÁCTEA SOBRE O CRESCIMENTO E SOBREVIVÊNCIA DE CORDEIROS SANTA INÊS}

\section{RESUMO}

Objetivou-se com este experimento avaliar os efeitos de métodos alternativos de suplementação de cordeiros em aleitamento sobre seu desempenho e sobrevivência. Foram utilizados 84 cordeiros Santa Inês, $50 \%$ machos e $50 \%$ fêmeas, de partos simples e gemelares. Os animais foram divididos em três tratamentos: A (controle), B $(200 \mathrm{~mL}$ de leite de vaca/animal/dia) e C $(200 \mathrm{~mL}$ de leite de vaca, mais $20 \mathrm{~g}$ de mistura múltipla/animal/dia). O experimento se inciou às três semanas de idade dos cordeiros e terminou ao desmame ( 2 meses). $\mathrm{O}$ peso dos ovinos ao desmame (PD) foi 10,90, 13,20 e 13,59 kg, para os tratamentos $\mathrm{A}, \mathrm{B}$ e $\mathrm{C}$ respectivamente, e o ganho médio diário (GMD) foi de 126, 163 e 168 g/animal/dia, respectivamente. A taxa de mortalidade foi maior $(\mathrm{P}<$ $0,05)$ no grupo A em relação aos grupos B e C. O sexo dos animais influenciou significativaente $(\mathrm{P}<0,05)$ o $\mathrm{GMD}$ e 
PD. GMD e PD foram menores para os ovinos que morreram em comparação aos que sobreviveram: $7,94 \mathrm{~kg}$ contra $13,51 \mathrm{~kg}$ e $77 \mathrm{~g}$ contra $165 \mathrm{~g}$, respectivamente. Os gêmeos apresentaram GMD e PD menores $(\mathrm{P}<0,05)$ que os de parto simples. A suplementação com ou sem a mistura múltipla se mostrou eficiente, podendo aumentar a produtividade do sistema de produção.

PALAVRAS-CHAVE: casca de ovo, folha de mandioca, ganho de peso, mortalidade

\section{INTRODUCTION}

The use of substitutes for milk in lamb feeding is widespread, occurring mainly with orphan animals or when ewes are used for milk production, and in such cases the substitute should be cheaper than milk ${ }^{1}$. Substitutes can also be used to eradicate a particular disease, such as Maedi-Visna, transmitted through natural suckling ${ }^{2}$. There have also been issues related to animal welfare. Napolitano et al. ${ }^{3}$ and Coulon ${ }^{4}$ reported that early separation of the infant from its dam (at two days old) and subsequent feeding with substitutes implied lower stress in lambs than taking longer time until weaning.

Lambs have a high growth capacity from birth until four to five months of age. During this phase, the lamb presents lower feed conversion, which increases thereafter. Therefore, these animals should have a higher daily weight gain if they are given dietary supplementation, compared to those that receive only milk from the dam. In cases of twins, this situation intensifies since the female may not produce enough milk for the lambs and consequently they will present lower daily weight gain and weaning weight compared to single animals $^{5}$. Tsiligianni et al. $^{6}$ showed that lambs receiving cow colostrum and reared artificially had no significant difference in passive immunity at fourweeks of age, when compared to a group reared by their dams.

The use of multi mixture flour (MMF) for child nutrition is widespread in Brazil, driven to the Children's Pastoral, as an alternative for infant nutrition in underdeveloped regions of the country. It is based on the use of food that is usually thrown away, including seed husks and leaves. MMF usually has high protein content, energy, mineral and vitamin levels, thus it may also be useful for supplementation in lamb nutrition; however, some authors discuss the real effectiveness of MMF. In experiments with rats, Ferreira et al. ${ }^{7}$ reported that while MMF used was able to supplement vitamins in relation to the control group, the same was not observed for minerals. These authors claim that chemical interactions between nutrients and the quantity of MMF supplied per day are important factors for adequate nutrition. High levels of carbohydrates present in the MMF ultimately dilute other nutrients. MMF may also contain antinutritional compounds, which may, in some cases, be toxic. Since this product is homemade, health problems can arise during its preparation. All these factors influence the ultimate effectiveness of MMF in combating malnutrition. Studies on MMF supplementation in lambs feed are scarce in the literature.

Santa Inês is the most widespread sheep breed in Brazil ${ }^{8}$ being used as both a maternal and paternal breed ${ }^{9}$. Several reports of low growth rates in lambs in Brazil have been found, and mortality rate in these cases can be high, with reports up to $50 \%{ }^{10}$. This may be due to undetected subclinical mastitis $^{11}$, as well as poor nutrition or low milk production by the dams. Supplementary feeding may increase growth rates and decrease mortality. This study aimed to evaluate the effect of alternative feeding methods along with maternal feeding of lambs using MMF on the survival and growth rates of lambs.

\section{MATERIAL AND METHODS}

The experiment was conducted in a region where the Koppen climate type is seasonal tropical (Aw), with seasonal rainfall, dry winters and rainy summers. The experimental period lasted 90 days (July to September), and was approved by the University Ethical Committee for Experiments with Animals (33/2009).

Eighty-four Santa Inês lambs were used, half of each sex, from both simple and twin births, at 21 days old until weaning at two months of age. From 5 $\mathrm{pm}$ to $8 \mathrm{am}$, all the lambs were kept with their dams, when they were suckled, and from 8 am to $5 \mathrm{pm}$ the dams were at pasture, and the lambs housed. The lambs received hay and concentrate diet ad libitum via creep feeding and were weighed every 15 days. The animals were divided into three groups: Group A (control group), Group B (200 $\mathrm{mL}$ of undiluted bovine milk) and Group C (20 g MMF mixed with $200 \mathrm{~mL}$ undiluted bovine milk); each group contained 28 animals, 14 males and 14 females. The animals of groups $\mathrm{B}$ and $\mathrm{C}$ had an adaptation period where they received $25 \%, 50 \%$ and $75 \%$ of the total diet for the first, second and third days, respectively. From the fourth day on they received the total diet. 
The liquid supplement was provided once daily, using feeding bottles. Lambs were weaned at 60 days of age and survival measured up to 30 days after weaning.

Bovine milk used was produced at the farm. MMF consisted of 5\% of eggshell powder, $20 \%$ dried and ground cassava leaf and $75 \%$ cassava flour (Table 1). The eggshell was processed as in Naves ${ }^{12}$ : shells were broken into pieces, washed in $1 \%$ sodium hypochlorite solution and then rinsed, dried in an oven at $60{ }^{\circ} \mathrm{C}$ for 48 hours, and then crushed in a grinder. The cassava leaf was sun-dried, spreading the leaves over black plastic at a $10 \mathrm{~cm}$ layer and turned daily. The cassava flour was purchased in the local market.

Table 1 - Nutritional analysis of experimental diets for Santa Inês lambs

\begin{tabular}{lccc}
\hline & Sheep's milk & Bovine milk & Multi-mixture flour \\
\hline Dry matter (\%) & 15.42 & 12.73 & 90.93 \\
Nonfat solids (\%) & 13.00 & 9.46 & - \\
Lactose (\%) & 7.03 & 5.19 & - \\
Density (g/mL) & 44.10 & 34.95 & - \\
Ash (\%) & 0.96 & 0.59 & 0.10 \\
Fat (\%) & 8.88 & 3.23 & 1.50 \\
Neutral detergent fiber (\%) & - & - & 21.15 \\
Acid detergent fiber (\%) & - & - & 8.50 \\
Protein (\%) & 4.92 & 3.56 & 5.43 \\
Non Nitrogen Extract (\%) & - & - & 63.33 \\
\hline
\end{tabular}

- Not measured.

Data were analyzed using MIXED, FREQ and CORR of SAS ${ }^{\circledR}$, (Cary, North Carolina, v.9.3) estimating the effect of treatment, sex of lamb, type of birth (single or double) on weights and growth rates as well as mortality. Pearson, Kappa and Spearman correlations were calculated depending on the type of data used. Survival (0 or 1 ) was analyzed using the LIFETEST and LOGISTIC procedures.

\section{RESULTS AND DISCUSSION}

There was no significant difference between genders or type of lambing for birth weight $(\mathrm{P}<0.05)$ (Table 2). Mortality was not affected by birth type, but the animals that died had grown more slowly than those who survived, and males and single born animals grew faster than females and twins. This has been seen in other studies ${ }^{10}$ where sexual dimorphism and limited feed supply for twin animals can affect growth rates. Studies show that nutrition is crucial for the proper growth of external and internal organs of lambs ${ }^{13}$. The animals that grew more slowly probably had dams that did not produce an adequate quantity of milk, having a nutritional deficit and inappropriate development, experiencing a situation that was incompatible with survival. In the case of twin pregnancies, the mother had to produce milk for more than one lamb; however, even in situations of single birth this production is often insufficient.

Table 2 - Weight and weight gain for Santa Inês lambs

\begin{tabular}{cccc}
\hline & $\begin{array}{c}\text { BirthWeight } \\
(\mathrm{Kg})\end{array}$ & $\begin{array}{c}\text { WeaningWeight } \\
(\mathrm{Kg})\end{array}$ & $\begin{array}{c}\text { Daily Weight Gain } \\
(\mathrm{g} / \text { day })\end{array}$ \\
\hline Sex: males & $3.45^{\mathrm{a}}$ & $13.27^{\mathrm{a}}$ & $162^{\mathrm{a}}$ \\
Females & $3.21^{\mathrm{a}}$ & $12.15^{\mathrm{b}}$ & $118^{\mathrm{b}}$ \\
Death: survived & $3.38^{\mathrm{a}}$ & $13.51^{\mathrm{a}}$ & $165^{\mathrm{a}}$ \\
died & $3.14^{\mathrm{a}}$ & $7.94^{\mathrm{b}}$ & $77^{\mathrm{b}}$ \\
Birth type: simple & $3.37^{\mathrm{a}}$ & $13.08^{\mathrm{a}}$ & $160^{\mathrm{a}}$ \\
twin & $3.21^{\mathrm{a}}$ & $9.37^{\mathrm{b}}$ & $100^{\mathrm{b}}$ \\
\hline
\end{tabular}

${ }^{a, b}$ Different letters in the same column are different $(\mathrm{P}<0.05)$, using Duncan's test. 
The nutrient requirements of gestating sheep with two lambs are larger than those with a single lamb, and depend on the phase of fetal development or lactation. Dietary restriction of females, especially in the last third of gestation, ultimately interferes with the proper development of the lambs ${ }^{13}$. According to Santra and Karim ${ }^{14}$ the growth of lambs until the first month of life primarily depends on the dam milk production, which is a function of the body condition of the sheep and its feeding regime during lactation. The experiment was held in the dry period when the conditions of pastures are very poor which may have affected dam milk supply.

The time needed to reach slaughter weight depends on the dam nutrition during lactation and the quality of the feed available. Pires et al. ${ }^{15}$ and Pires et al. ${ }^{16}$ observed that lamb quality improves (higher dressing percentage and higher production efficiency) with high growth rate. According to Jenness $^{17}$, sheep milk has higher energy content than bovine milk and the physical volume of the lamb abomasum is the primary limit to the total consumption. Any replacement must provide a quality substitute that has a high energy content to have greater feed efficiency.

There was no significant difference between the two groups receiving bovine milk in terms of growth and final weight (Table 3), but the control group grew more slowly than the others $(\mathrm{P}>0.05)$. This difference was evident within the first 15 days (weight at 30 days). This shows that nutrition plays a key role in the early development of lambs. Ferreira et al. ${ }^{7}$, studying MMF in mice, found that the way MMF is administered means that nutrients are supplied in small quantities, possibly being diluted and interactions may also occur between the different nutrients when mixed, making them unavailable to the animal, which may account for the lack of significant difference between treatments B and

Table 3 - Least square means for weights $(\mathrm{kg})$ of lambs per treatment and sex

\begin{tabular}{lccccc}
\hline & \multicolumn{5}{c}{ Age (days) } \\
& Birth & 15 & 30 & 45 & 60 \\
\hline Bovine Milk + MMF Male & $3.36^{\mathrm{a}}$ & $7.10^{\mathrm{a}}$ & $9.98^{\mathrm{a}}$ & $11.94^{\mathrm{a}}$ & $13.65^{\mathrm{a}}$ \\
Bovine Milk + MMF Female & $3.28^{\mathrm{a}}$ & $7.74^{\mathrm{a}}$ & $10.94^{\mathrm{a}}$ & $12.83^{\mathrm{a}}$ & $13.54^{\mathrm{a}}$ \\
Bovine Milk Male & $3.72^{\mathrm{a}}$ & $7.67^{\mathrm{a}}$ & $9.89^{\mathrm{a}}$ & $11.94^{\mathrm{a}}$ & $13.12^{\mathrm{a}}$ \\
Bovine Milk Female & $3.02^{\mathrm{a}}$ & $7.79^{\mathrm{a}}$ & $10.39^{\mathrm{a}}$ & $12.26^{\mathrm{a}}$ & $13.28^{\mathrm{a}}$ \\
Control Male & $3.19^{\mathrm{a}}$ & $6.70^{\mathrm{a}}$ & $8.07^{\mathrm{b}}$ & $9.76^{\mathrm{b}}$ & $10.61^{\mathrm{b}}$ \\
Control Female & $2.72^{\mathrm{a}}$ & $6.03^{\mathrm{a}}$ & $7.49^{\mathrm{b}}$ & $9.03^{\mathrm{b}}$ & $11.20^{\mathrm{b}}$ \\
\hline
\end{tabular}

${ }^{\mathrm{a}, \mathrm{b}}$ Different letters in the same column are different $(\mathrm{P}<0.05)$, using Duncan's test; MMF - Multimixture flour

In terms of survival, while there was no difference between the death rate for males, females, simple or twin births, the death rate in the control group was more than twice that of the other groups $(\mathrm{P}<0.05)$ (Table 4). The deaths in this group were probably due to inadequate milk production by dams. The animals failed to develop properly compared to those that were supplemented. Therefore, supplementation was shown as an appropriate measure in reducing the mortality of lambs. Tsiligianni et al. ${ }^{6}$ also found no difference between lambs reared artificially or naturally after 28 days of life, indicating that as long as they are adequately fed, the manner of feeding is not important.

Table 4 - Mortality due to sex, treatment and type of delivery in Santa Inês lambs

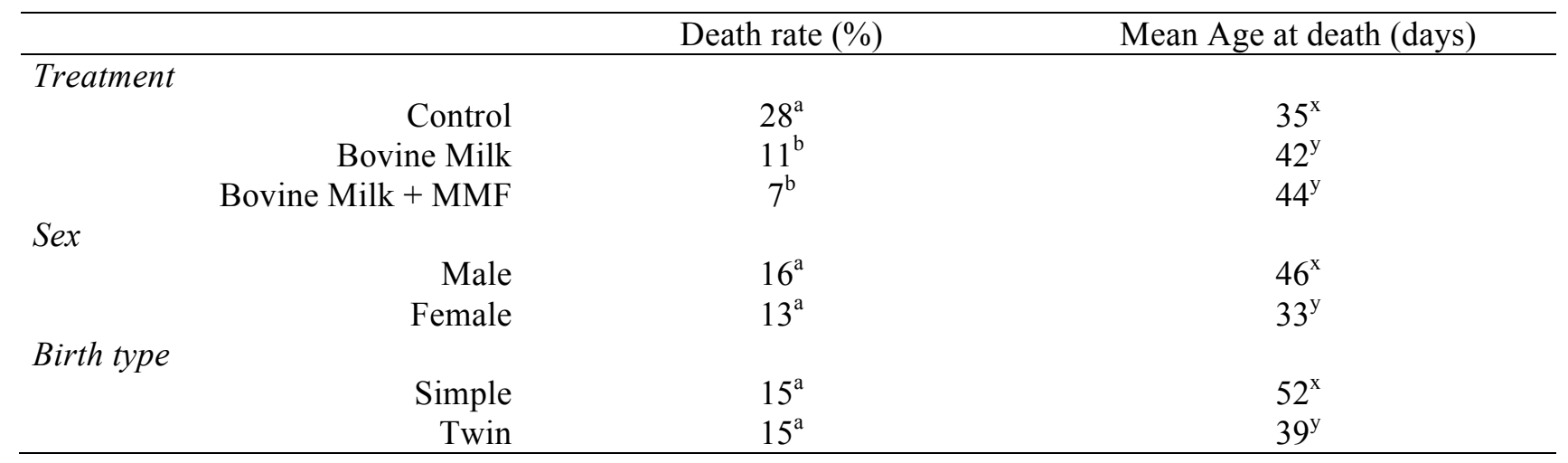

${ }^{\mathrm{a}, \mathrm{b}}$ Different letters in the same column are different $(\mathrm{P}<0.05)$, using the Chi square test 
There was also a tendency for the control animals and twins to die earlier (Figure 1) than the other animals, probably due to a lack of nutrients for growth in both these groups ${ }^{7}$. No difference in survival rate was seen between the two supplementation treatments, showing that MMF did not improve survival over the use of bovine milk alone. This probably indicates that sufficient nutrients were obtained from milk alone or that
MMF did not supply additional nutrients to increase growth rates or survival.

Weight gain was the single most important effect influencing survival of lambs (Figure 2). A daily gain above $100 \mathrm{~g}$ per day showed a greater than $80 \%$ chance of survival. Therefore, any treatment that increases lamb growth in this period should increase survival rates in these lambs.
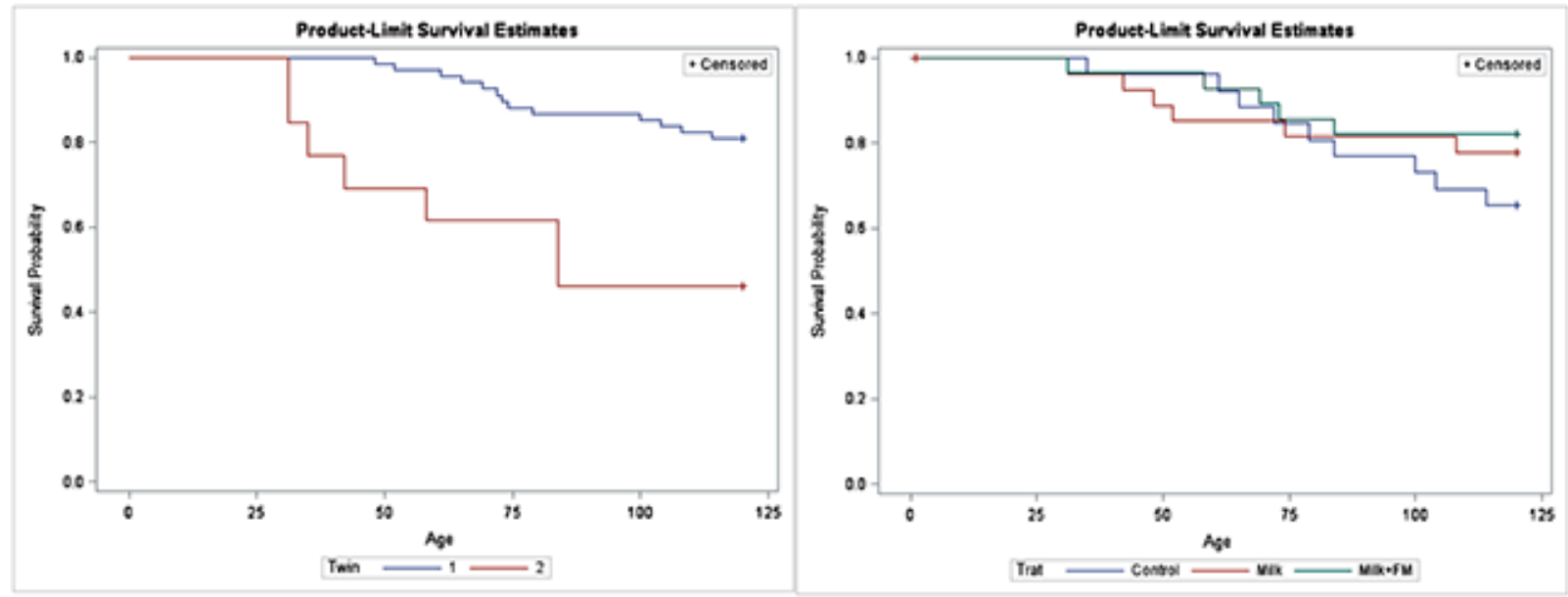

Figure 1 - Life test survival comparison due to type of birth (A) and milk supplementation (B) in Santa Inês lambs.

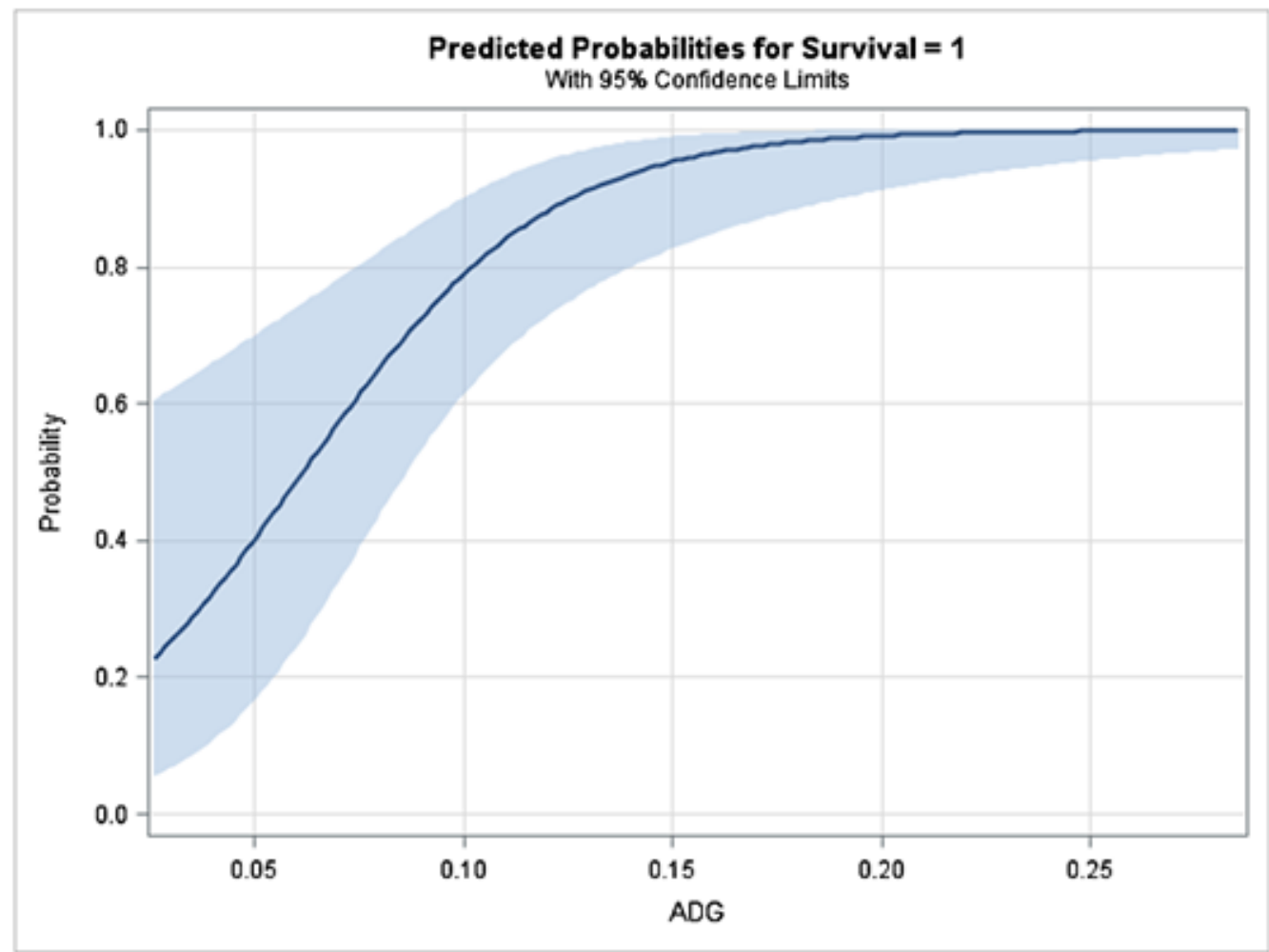

Figure 2 - Logistic survival regression of Santa Inês lamb survival due to their average daily gain (ADG). 
The correlations of other traits with birth weight were low (Table 5). This shows that postnatal factors are important in determining age of death and if the animal dies. Weight gain had a high negative correlation with age at death - those lambs that grew faster survived for a longer time or did not die, confirming the results found in Figure 2.

Table 5 - Correlations between the measures in Santa Inês lambs

\begin{tabular}{lccccc}
\hline & PN & WW & ADG & Twin & Age of death \\
\hline WW (kg) & 0.33 & & & & \\
ADG (g/day) & 0.16 & -0.23 & & & \\
Twins & -0.09 & -0.01 & -0.30 & & \\
Age of death (days) & -0.12 & -0.40 & -0.87 & -0.51 & -0.09 \\
Died (0 or 1) & -0.12 & -0.49 & -0.05 & -0.01 & \\
\hline
\end{tabular}

WW-weaning weight; BW-birth weight; ADG- daily weight gain; twin -birth type (1 or 2 lambs).

\section{CONCLUSION}

The period from birth to weaning is important for the growth and survival of lambs. Supplementation can improve production rates even in suckling lambs. Multi mixture flour did not show improvements beyond supplying bovine milk.

\section{ACKNOWLEDGEMENTS}

To FAPDF and INCT - Pecuária (MCT/CNPq/FAPEMIG) and CNPq for funding and scholarships.

\section{REFERENCES}

1. Fontes FAPV, Coelho SG, Lana AQM, Costa TC, Carvalho AU, Ferreira MIC, Saturnino HM, Reis RB, Serrano AL, 2006. Desempenho de bezerros alimentados com dietas líquidas à base de leite integral ou soro de leite. Arquivo Brasileiro de Medicina Veterinária e Zootecnia. 2006; 58(2): 212-219.

2. Polledo L, González J, Fernandéz C, Miguélez J, Martínez-Fernandez B, Morales S, Ferreras MC, Marín JFG. Simple control strategy to reduce the level of Maedi-Visna infection in sheep flocks with high prevalence values $(>90 \%)$. Small Ruminant Research. 2013; 112(1-3): 224-229.

3. Napolitano F, De Rosa G, Sevi A. Welfare implications of artificial rearing and early weaning in sheep. Applied Animal Behaviour Science. 2008; 110(1-2): 58-72.

4. Coulon M, Nowak R, Andanson S, Ravel C, Marnet PG, Boissy A, Boivin X. Human-lamb bonding: Oxytocin, cortisol and behavioural responses of lambs to human contacts and social separation. Psychoneuroendocrinology. 2013; 38(4): 499-508.
5. Paim TP, Cardoso MTM, Borges BO, Gomes EF, Louvandni H, McManus CM. Economic study of crosssbred feedlot lambs slaughtered at different weights. Ciencia Animal Brasileira. 2011; 12(1):48-57.

6. Tsiligianni Th, Dovolou E, Amiridis GS. Efficacy of feeding cow colostrum to newborn lambs. Livestock Science. 2012; 149(3): 305-309.

7. Ferreira HS, Assunção ML, França AOS, Cardoso EPC, Moura FA,. Efetividade da "multimistura" como suplemento de dietas deficientes em vitaminas e/ou minerais na recuperação ponderal de ratos submetidos à desnutrição pós-natal. Revista de Nutrição. 2005; 18(1): 63-74.

8. McManus C, Hermuche P, Paiva SR, Melo CB, Mendes CQ. Geographical distribution of sheep breeds in Brazil and their relationship with climatic and environmental factors as risk classification for conservation. Brazilian Journal of Science and Technology. 2014; 1(1-3): 1-15.

9. McManus C, Paiva SR, Araújo RO. Genetics and breeding of sheep in Brazil. Revista Brasileira de Zootecnia. 2010; 39 (Special issue): 236-246.

10. Paim TP; Silva AF, Martins RFS, Borges BO, Lima PMT, Cardoso CC, Esteves GIF, Louvandini $H$, McManus C. Performance, survivability and carcass traits of crossbred lambs from five paternal breeds with local hair breed Santa Inês ewes. Small Ruminant Research. 2013; 112(1-3): 28-34.

11. Martins RFS, Paim TP, Cardoso CA, Dallago BSL, Melo CB, Louvandini H, McManus C. Mastitis detection in sheep by infrared thermography. Research in Veterinary Science. 2013; 94(3): 722-724.

12. Naves, MMV. Pó da casca de ovo como fonte de cálcio: qualidade nutricional e contribuição para o aporte adequado de cálcio. Revista da PROEC [Internet]. 2003 Apr [Cited 2003 Oct 10]; 5(1): 1-6. Available from: http://www.proec.ufg.br/revista_ufg/fome/casca.html.

13. Geraseev LC, Perez JRO, Pedreira BC, Quintão FA, Oliveira RP. Efeito da restrição alimentar pré e pós-natal 
sobre o crescimento dos órgãos internos de cordeiros Santa Inês. Arquivo Brasileiro de Medicina Veterinária e Zootecnia. 2008; 60(4): 960-969.

14. Santra A, Karim SA. Effect of protein levels in creep mixture on nutrient utilization and growth performance of pre-weaner lambs. Small Ruminant Research. 1999; 33(2): 131-136.

15. Pires CC, Silva LF, Farinatti LHE, Peixoto LAO, Fülber ME, Cunha MA. Crescimento de cordeiros abatidos com diferentes pesos: 2 . Constituintes corporais. Ciência Rural. 2000; 30(5): 869-873.

16. Pires CC, Silva LF, Schlick FE, Guerra DP, Biscaino G, Carneiro RM. Cria e terminação de cordeiros confinados. Ciência Rural. 2000; 30(5): 875-880.

17. Jenness R. Lactational performance of various mammalian species. Journal of Dairy Science. 1986; 69(3): 869-885.

Protocolado em: 27 jan. 2010. Aceito em: 16 set. 2014. 